Прокопів А. М.", orcid.org/0000-0001-8661-510X

Сидорук О. М., orcid.org/0000-0002-7173-5798

\title{
ОСОБЛИВОСТІ УКРАЇНІЗАЦЇ̈ ШКОЯИ В ЗАХІДНОМУ РЕГІОНІ УКРАЇНИ У ПЕРШІЙ ПОЛОВИНІ ХХ СТ.
}

Статтю присвячено вивченню історико-педагогічних напрацювань з проблеми українізації школи в Західному регіоні України на початку XX століття.

Авторали проаналізовано особливості та важливі чинники збереження украйнської школи та освіти: соцзіально-політичні (розпад ілперій $i$ створення ЗУНР, штучна територіальна розмежованість, насильницька політика чужих держав та існування в межах таких держав, відсутність прав українців на повноцинну освіту), економічні (відсталість, слабкий розвиток економіки та промисловості), культурні (низький рівень розвитку загальної культури, зневага до украӥнського населення тощцо).

У статті на основі аналізу джерельної бази (архівні матеріали, наукові дослідження сучасних науковців) визначено важливі проблеми, напрялки, засоби збереження української мови та щколи.

Авторами розширено уявлення про можливості школи та вчителя в Західній Украйні на початку XX століття задля збереження українських ідей і націй загалом.

У статті доведено думку про національне виховання як основну мету школи, а саме те, що західноукраїнські освітяни постійно опікувалися проблемами розвитку щколи, основою якої стало українознавство, щзо відповідало меті та змісту виховувального навчання.

3'ясовано, що збереженню та розвитку української національної школи сприяло розширення мережі приватних навчальних закладів, зокрема приватних гімназій.

Вивчені історико-педагогічні дослідження дозволили виокремити умови збереження украйнської школи, закцентувати увагу на особливостях навчальних курсів у школах Західної України на початку XX століття, що мали великий вплив на ї̈ украйнізаціюо.

Автори наголошують, щзо дослідження проблем українізації школи потребують детального наукового вивчення для екстраполяції досвіду в сучасне шкільництво.

Ключові слова: Західна Украйна, національна школа, украйнізаціл, націоналізаціл, шкільна освіта, украӥнська мова.

Постановка проблеми. На сьогодні актуалізується питання єдності України. Воно неможливе без української школи, національної ідеї. Саме тому варто повернутися до досвіду минувшини. Уміння українців у той час вижити в межах різних чужих політичних націй - важлива особливість збереження українства. Школа - той інструмент, який оберігає й розвиває націю, створює умови для кращого життя українства. Це дуже важливо було в минулому столітті й необхідним є зараз.

Аналіз досліджень. Саме тому проблеми збереження української освіти в Західному регіоні привертають увагу сучасних науковців, дослідників історії шкільництва Західної України: Буковини (І. Житарюк, О. Пенішкевич та ін.), Галичини (Г. Білавич, Т. Завгородня, Г. Демко, Б. Савчук, В.Стинська та ін.), Водині (Д. Козоріз, Н. Рудницька та ін.), Закарпаття (В. Гомонай, О. Фізеші та ін.).

Загалом питання українізації шкіл України в 20-30-х роках XX століття детально проаналізували В. Кузьменко, Н. Слюсаренко. Автори акцентували на якісно новій ролі української школи в суспільному житті у 20-ті - на початку 30-х років XX століття [10].

*C Прокопів Л. М.

*(C) Сидорук O.M.

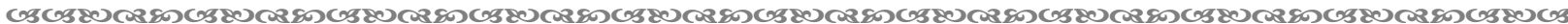


Особливої уваги варті дослідження Т. Завгородньої, яка не лише детально вивчила дидактичну думку Галичини (1919/1939рр.), а й показала особливості навчання українською мовою та проаналізувала творчу спадщину галицьких українських педагогів [5, с. 78-79].

У публікації Б. Ступарика проаналізовано еволюцію національної школи, збереження української мови й національного виховання в педагогічній думці Галичини, зокрема, висвітлено концептуальні засади національного шкільництва [16, с. 1]. У контексті сказаного детального вивчення потребують особливості українізації школи в Західній Україні.

Мета статті - з'ясувати, спираючись на сучасні наукові доробки та архівні джерела, особливості збереження української мови та освіти в Західній Україні на початку XX ст.

Виклад основного матеріалу. Вирішальне значення в розвитку нації має мова, бо саме в ній закладаються основи не тільки знань, але й громадянської свідомості. Це стосується бездержавного народу (як-от українців на окупованих територіях уміжвоєнний період), який лише завдяки мові, релігії, націонадьній культурі i, не в останню чергу, освіті мав змогу зберегти етнічну спільноту, не втратити надію на здобуття незалежності.

Українізація в Західній Україні в розумінні збереження української мови полягала передусім у боротьбі за українську національну школу.

Важливим аспектом збереження української мови була початкова школа, бо в середніх школах, а тим більше - вищих, мова викладання була, як правило, не рідна. Для початкових шкіл в Західній Україні був характерний утраквізм (двомовність). Тому для сіл (а села в Західній Україні були переважно українськими) існування національної школи було дуже важливим і навіть доленосним. Питання українізації школи в Західній Україні на початку XX ст. набуває не лише освітянського, але й набагато ширшого - соціально-політичного значення.

Загалом українізація в Західній Україні зумовлена низкою чинників:

по-перше, соціально-політичними обставинами, які впливали на розвиток освіти й на формування іï змісту. Відомо, що Західна Україна в перші десятиріччя XX століття в економічному відношенні була дуже відсталою (не розвивалася промисловість, сільське господарство занепадало, країни-окупанти не мади на меті розвивати економіку на західноукраїнських землях);

по-друге, позитивні зміни в українізацію приніс розпад Австро-Угорської імперії, що було використано як можливість для відродження своєї державності. Українці, які жили на західних територіях України, що входила до складу Польщі, Чехословаччини, Румунії, зазнавали утисків, бо визвольні змагання не призвели до бажаного результату.

Серйозною спробою утвердження власної держави стало прогодошення ЗахідноУкраїнської Народної Республіки (ЗУНР) у листопаді 1918 р. 75 \% ЗУНР, як стверджують дослідники, складали українці, поляки - $12 \%$, євреї - $11 \%$, решта - інші національності [2, с. 114].

Уряд ЗУНР сприяв розвитку української мови, робив все для розширення мережі українського шкільництва. Зокрема, ним прийнято закон від 10 лютого 1919 р., згідно 3 яким українська мова проголошувалася державною.

Питання українізації розв'язувалося так: при проживанні у місцевості, де більшість українців, відкривались українські школи. У містах створювалися утраквістичні (двомовні) школи. В усіх польських школах обов'язковим предметом вивчання була українська мова.

Ще одним чинником іiі збереження стало створення приватних шкіл, гімназій. Саме тут зберігався український дух та ідеї українства. В архівних джерелах ми, аналізуючи журнали шкіл, знаходили записи вчителів та директорів польською мовою. У 1919 році такі записи стали вже україномовними.

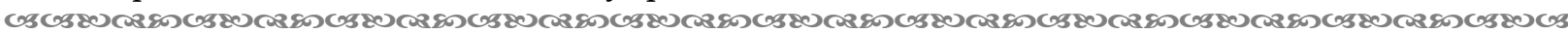
264 
Велику увагу розвитку українського шкільництва в Західній Україні приділяли товариства «Просвіта», «Рідна Школа», які видавади підручники і посібники, зокрема «Буквар», читанки для II-IV класів тощо [16].

у книзі «Товариство «Рідна школа» Г. Білавич і Б. Савчук стверджують, що українські приватні початкові школи стали основою боротьби українського народу за українізацію школи. «Рідна Школа» утримувала 33 середні школи 3 загальною кількістю понад 6000 учнів [1, с. 110].

Приватне шкільництво в ті часи було одним з дієвих засобів, що протидіяв постійному намаганню офіційної влади поступово знищувати українські школи. Зокрема, набула поширення система приватного домашнього навчання. Причому рівень освіти дітей у таких школах був вищий, ніж учнів у державній школі [1, с. 109].

У ті часи «всюди з виїмком подьських громад, викладовий язик український, понехано святкованне свят латинських, понехано науку виступів 3 історії Подьщі і бувшої Австрії, понехано науку польської мови з виїмком громад чисто польських, а в громадах, де людність польська становить $25 \%$, наука подьської мови маєся уділяти доперло на 3 році і то в двох годинах тижнево» [6, с. 19].

Цей запис підтверджує думку, що про свою державу і мову дбали не тільки державні службовці, а й директори шкіл, учителі. У 1921 р. Польською конституцією введено право спілкуватися українцям рідною мовою та навчатися нею в початкових школах. Однак, від 1921 року, за даними статистики, українське населення зменшувалося й кількість україномовних шкіл зменшувалося також. Розуміючи загрозу з боку української громади, яка прагнула до вільної і незалежної держави, польська влада робила все, щоби перешкодити піднесенню національної ідеї. У той час зменшувалася частка україномовних навчальних закладів: 3793 (1924р.) до 337 (1927 p.) [11, c. 66].

Українське шкільництво ополячувалося або утраквізувалося й було в руках польських учительських сил, тому не приносило користі українцям.

Сільські школи, які мали один чи два класи, показували низький рівень знань з української мови. Вони ставали практично бездіяльними. «Про дискримінаційний характер тогочасного шкільного устрою можна судити 3 того, що шість років навчання в одно- чи двокласній школах прирівнювали до чотирьох років в трикласній і два роки в чотирикласній, шість років навчання в трикласній - до чотирьох років у чотирикласній» [5].

На початку 30-х років XX ст. була зроблена спроба українізації на західноукраїнських землях. Польським урядом 11 березня 1932 р. було прийнято рішення змінити структуру освіти. Навчання в школах розподілялося відповідно до трьох концентрів. 1 ступінь - 1-4 класи. Тут діти навчалися читанню і письму. 2 ступінь - 5-6 класи. У них займалися в основному практичними завданнями й мали господарське спрямування. 3 ступінь - 7 клас. Учні поглиблювали свої знання й мали право вступати до навчальних закладів середнього типу.

3 одного боку, видавалося, що така реформа сприятиме українізації школи. Але на практиці шкіл другого/третього ступенів було дуже мало.

Свідчення цього находимо в архівних матеріалах: «Наш нарід обдарований самими тільки однокдясівками, рідше двокдясівками, дуже рідко трикдясівками, а чотири- і більше - клясівок у нас зовсім немає» [9, с. 16]. У цей час українцям не дозволялося навчатися в державних навчальних закладах, що приводило до ополячення українського народу.

Небажання поляків сприяти українським дітям в отриманні української початкової освіти спричинило до організації приватних міських навчальних закладів. Їх відкривали в основному громадські та релігійні організації (або за рахунок громад). Саме такі приватні школи мали провідне місце в українізації, зокрема в піднесенні освіти й культури українців в Західній Україні.

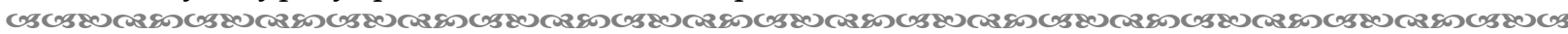
265 
Так, у Станіславському (нині Івано-Франківщина) повіті були 4 українські приватні школи, а в Тернопільському - 4 міські і 2 сільські школи. Ось як пише про приватні школи А. Крушельницький: «...всі поневолені народи, оскільки вони не затратили своєї національної чести й гідності, мусять закладати свої приватні школи на те, щоб у них, незалежно від чужої школи й чужого вчителя, давати своїй молоді такий світогдяд, якого вимагає інтерес нації» [13, с. 91].

Що ж до українського села, воно в основному було неписьменним.

На Волині польська влада, розуміючи вплив галичан, намагалася обмежити контакти між гадичанами та волинянами. Там кураторіум проводив політику обмеження викладання українською мовою, закривав українські школи. Українських шкіл у цій місцевості майже не було, а української мови зазвичай навчали польські вчителі, які самі не володіли нею. У таких школах виховували не українців, а «добрих поляків». Українських учителів пригнічували, їх кількість зменшувалася.

Національний склад учнів станом на 1925 р. у Рівному (Волинський кураторіум) подано на рис. 1.

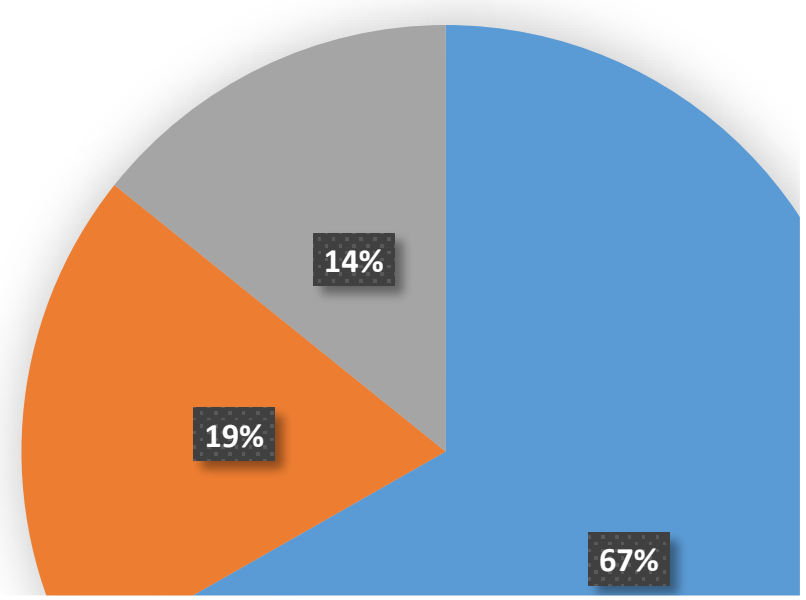

Рис. 1. Кількість украӥнського икільництва на Волині (1925 р.)

У той час навчали цих дітей $76,6 \%$ вчителів-поляків і $17,6 \%$ вчителівукраїнців [15, с. 16].

Такі ж дані простежуємо в закладах із підготовки вчителів для українських початкових шкіл. Зокрема, серед 13 викладачів державного педагогічного діцею тільки 4 знали українську мову [14, с. 10]. А україномовних вчителів відправляли працювати в польські навчальні заклади. Така ж ситуація тривала і в середніх навчальних закладах, куди практично не допускади українців. Наслідком такого ставлення поляків до українства стала його неграмотність.

Якщо у Галичині українські школи існували за рахунок товариства «Рідна Школа», то на Волині не функціонувало ніяких українських громадських товариств і приватних навчальних закладів.

У журналі «Українська школа» зазначено, що на Поліссі та Демківщині українських шкіл майже не було, а вивчення української мови мало дуже поверховий характер. 3 цього приводу І. Герасимович пише: «У нас в школі вчать тільки три рази на тиждень української мови. В першій клясі зовсім не вчать української мови, в другій вчать, але дуже мало. Не вчать українських пісень, тільки польські» [3, с. 155].

Таким чином, стан українського шкільництва в Західній Україні був надзвичайно важким. Польська влада всіляко боролася з українізацією.

Драматична доля спіткала й українські школи Буковини, яка була під владою Румунії. Відомо, що «до часу приєднання Буковини до румунської держави було там 218 народніх шкіл із українською викладовою мовою, 10 шкіл було із мовою 
українською і німецькою, 2 школи з українською і румунською а 4 школи 3 українською, німецькою й румунською. В більшості мішаних українсько-румунських громад існували цілком окремі й самостійні школи українські і румунські» [7, с. 4].

Під час румунізації всіх видів шкільництва в Буковині, до 1927 р., навчання рідною мовою не проводилося. Аюди почували себе у відчаї. Румунська влада робила все для того, щоб проводити політику румунізації. Зокрема, був виданий наказ, згідно 3 яким всіх дітей, що народидися після 1918 року, записували як румунів [4, с. 48]. Унаслідок цього в одній українській родині батьки були українцями, а діти - румунами.

У цей час на Буковині майже не було українських учителів. У законі від 26.07.1924 року читаємо, що «горожани румунського походження, які забули свою рідну мову, зобов'язані висилати своїх дітей тільки до громадських чи приватних шкіл із румунською викладовою мовою» [8, с. 365]. Таким чином, на території Буковини до 1927 р. були ліквідовані українські школи.

Однак, залишалися ще острівці українізації. Зокрема, буковинці (як і галичани) бородися за навчання українською мовою, писали дистівки, закдики до єднання, організовували робітничі та селянські віче. У тих українських громадах, де за часів Австрії не було школи, українці домагалися «відкриття українських кафедр - мови, літератури та історії - та утворення двох українських учительських семінарій - жіночої і хлоп'ячої - в Чернівцях. Усунення із шкіл усіх учителів, що не володіють українською мовою, і повернення до роботи всіх тих учителів, що їх раніш викинуто із шкіл або перенесено на румунську територію» [12, с. 156]. Однак ці вимоги не були виконані.

Українізація на теренах Буковини частково, лише у початкових школах, розпочалася 3 грудня 1929 р. відповідно до закону, який дозволяв у школах 3 чисельністю українців понад 51 \% вводити в початкових класах навчання українською мовою. Становище, в якому опинилося українське населення Буковини, зумовило пожвавлення української просвітницької і культурно-громадської діяльності. Якщо на Галичині українці зуміли протистояти полонізаційним процесам в освіті завдяки створенню приватного шкільництва, то на Буковині засновувати приватні школи було офіційно заборонено.

Боротьба українського населення Буковини за збереження українського шкільництва не принесла результату, діти-українці не мали змоги навчатись у рідномовних школах.

Висновки. Отже, можна констатувати, що в цілому західноукраїнське шкільництво на початку XX ст. було у важкому стані. Але, незважаючи на економічні та політичні обставини, все ж таки школа на західноукраїнських землях продовжувала існувати. Освітянам допомагало усвідомлене бажання не лише порятунку школи, а й збереження національної ідентичності. Дослідники історії західноукраїнського шкільництва одностайні в тому, що тільки завдяки відданості педагогів національній ідеї та одержимій праці в умовах чужої держави з'явились обгрунтовані засади формування змісту освіти, а одночасно й національної свідомості української мододі. Сказане має важливе значення стосовно саме початкової шкоди, яка, по суті, є осередком початку свідомого життя дитини.

Основною метою українізації західноукраїнських шкіл стало національне виховання. Освітяни постійно опікувалися питаннями змісту освіти, наріжною віссю якого мало стати українознавство, що відповідало гаслу виховувального навчання. Ще одним важливим чинником становлення й розвитку українського шкільництва стала участь громадських організацій, всього українського народу. Аналіз історикопедагогічних умов українізації школи на західноукраїнських землях доводить, що українці, які проживали на їі теренах, прагнули створити все необхідне для розвитку українського шкільництва.

В умовах штучної територіальної розмежованості західноукраїнських земель чужодержавними режимами українське шкільництво в межах польської та румунської

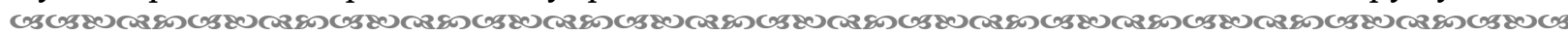
267 
держав зазнавало серйозних утисків, підпорядковувалося загальнодержавним освітнім напрямам, спрямованим на асиміляцію національних меншин.

Перспективним у нашому дослідженні є визначення впливу педагогів на українізацію школи в другій половині XX ст.

\section{Список використаних джерел:}

1. Білавич Г., Савчук Б. Товариство «Рідна школа». Івано-Франківськ: Лілея-НВ, 1999. 208 с.

2. Великочий В. Національна політика ЗУНР у контексті українсько-польських відносин: джерелознавчий аспект. Украӥнсько-польські відносини в Галичині у ХХ ст.: мматеріали міжнародної науково-практичної конференції (21-22 листопада 1996 р.). Івано-Франківськ: Плай, 1997. C. 113-117.

3. Герасимович I. За українську школу під Польщею. Діло. 1928. Ч. 65. С. 1-2.

4. Далавурак С., Мацьога Р. Занепад освіти на Буковині під час румуно-боярської окупації (1919 - 1940 рр.). Розвиток педагогічної освіти і науки в західних областях України. Тернопіль, 1990. Ч. 1. С. 47-49.

5. Завгородня Т. Дидактична думка в Галичині (1919-1939). Івано-Франківськ: Плай, 1998. 166 с.

6. Информация директора о работе школы. Державний архів Івано-Франківської області (ДАІФО). Ф. 590, оп. 1, спр. 1.33 арк.

7. Карбулицький I. Сумерк українського шкільництва на Буковині. Рідна щкола. 1932. Ч. 1. C. 4-5.

8. Квітковський Д., Бридзан Г., Жуковський А. Буковина: iii минуле i сучасне. ПарижФіладельфія-Дітройт, 1956. 965 с.

9. Криза народної освіти. Учительське слово. 1926. Ч. 2. С. 13-20.

10. Кузьменко В. В., Слюсаренко Н. В. Українізація шкіл України в 20-30-х роках ХХ століття. Педагогічний альманах: збірник наукових праць / редкол. В. В. Кузьменко (голова) та ін. Херсон: КВН3 «Херсонська академія неперервної освіти», 2019. Випуск 44. С. 241-248.

11. Мій рідний край - Прикарпаття. Івано-Франківськ: Плай, 2000. 376 с.

12. Піддубний Г. Буковина: іiі минуле і сучасне. Харків: Державне видавництво України, 1928. $255 \mathrm{c}$.

13. Рецензії на шкільні підручники (буквар і читанку А.Крушельницького). Центральний державний історичний архів Украйни у м. Аьвові. Ф. 361, оп. 1, спр. 172. 46 арк.

14. Списки школ, учителей и учащихся г. Станислава за 1939 год. ДАІФО. Ф. Р-2, оп. 1-д, спр. 2. 104 арк.

15. Статистические данные о начальных и семилетних школах, национальном составе учеников Сарненского повета за 1936 год. Державний архів Волинської області. Ф. 454, оп. 2, спр. 655. 26 арк.

16. Ступарик Б. Школі - національне виховання молоді: вибрані статті. Івано-Франківськ: Плай, 2005. $283 \mathrm{c}$.

17. Шестиклассная публичная школа с польско-украинским языком преподования в с. Козари Рогатинского повета. ДАІФО. Ф. 590, оп. 1, спр. 1.33 арк.

\section{Referenses:}

1. Bilavych, H., \& Savchuk, B. (1999). Tovarystvo «Ridna shkola» [Society "Native School"]. IvanoFrankivsk: Lileia-NV [in Ukrainian].

2. Velykochyi, V. (1997). Natsionalna polityka ZUNR u konteksti ukrainsko-polskykh vidnosyn: dzhereloznavchyi aspect [National policy of the Western Ukrainian People's Republic in the context of Ukrainian-Polish relations: source study aspect], Ukrainsko-polski vidnosyny $v$ Halychyni u XX st., materialy mizhnarodnoi naukovo-praktychnoi konferentsii (21-22 lystopada 1996 r.) [Ukrainian-Polish relations in Halychyna in the twentieth century, Proceedings of the International Scientific and Practical Conference]. Ivano-Frankivsk [in Ukrainian].

3. Herasymovych, I. (1928). Za ukrainsku shkolu pid Polshcheiu [About the Ukrainian school near Poland]. Dilo, 65, 1-2 [in Ukrainian].

4. Dalavurak, S., \& Matsoha, R. (1990). Zanepad osvity na Bukovyni pid chas rumuno-boiarskoi okupatsii (1919-1940 rr.) [Decline of education in Bukovina during the Romanian-boyar occupation (1919-1940)]. Rozvytok pedahohichnoi osvity i nauky v zakhidnykh oblastiakh Ukrainy, 1, 47-49 [in Ukrainian]. 
5. Zavhorodnia, T. (1998). Dydaktychna dumka v Halychyni (1919-1939) [Didactic thought in Halychyna (1919 - 1939)]. Ivano-Frankivsk: Plai [in Ukrainian].

6. Informatciia direktora o rabote shkoly [Information of the director about the work of the school] (Fund 590. Inventory 7. File 1). State Archives of Ivano-Frankivsk Region, Ivano-Frankivsk [in Russian].

7. Karbulytskyi, I. (1932). Sumerk ukrainskoho shkilnytstva na Bukovyni [Twilight of Ukrainian schooling in Bukovyna]. Ridna shkola, 1, 4-5 [in Ukrainian].

8. Kvitkovskyi, D., Brydzan, H., \& Zhukovskyi, A. (1956). Bukovyna: yii mynule i suchasne [Bukovyna: its past and present]. Paryzh-Filadelfiia-Ditroit [in Ukrainian].

9. Kriza narodnoi osvity [The crisis of public education]. (1926). Uchytelske slovo, 2, 13-20 [in Ukrainian].

10. Kuzmenko, V. V., \& Slyusarenko, N. V. (2019). Ukrainizatsiia shkil Ukrainy v 20-30-kh rokakh XX stolittia [Ukrainization of Ukrainian schools in the 1920s and 1930s]. Pedahohichnyi almanakh, 44, 241-248 [in Ukrainian].

11. Kononenko, V. (Ed.). (2000). Mii ridnyi krai - Prykarpattia [My native land is Prykarpattia]. IvanoFrankivsk: Plai [in Ukrainian].

12. Piddubnyi, H. (1928). Bukovyna: yii mynule i suchasne [Bukovyna: its past and present]. Kharkiv: Derzhavne vydavnytstvo Ukrainy [in Ukrainian].

13. Retsenzii na shkilni pidruchnyky (bukvar i chytanku A.Krushelnytskoho) [Reviews of school textbooks (primer and reading book by A. Krushelnytskyi)] (Fund 361. Inventory 1. File 172). Central State Historical Archive of Ukraine in Lviv, Lviv [in Ukrainian].

14. Spiski shkol, uchitelei i uchashchikhsia g. Stanislava za 1939 god [Lists of schools, teachers and students of Stanislav] (Fund R-2. Inventory 1-d. File 2). State Archives of Ivano-Frankivsk region, Ivano-Frankivsk [in Russian].

15. Statisticheskie dannye o nachalnykh i semiletnikh shkolakh, natcionalnom sostave uchenikov Sarnenskogo poveta za 1936 god [Statistics on primary and seven-year schools, the national composition of students of Sarny district for 1936]. (Fund 454. Inventory 2. File 655). State Archives of Volyn Region, Lutsk [in Russian].

16. Stuparyk, B. (2005). Shkoli - natsionalne vykhovannia molodi [Schools - national education of youth (selected articles)]. Ivano-Frankivsk: Plai [in Ukrainian].

17. Shestiklassnaia publichnaia shkola s polsko-ukrainskim iazykom prepodovaniia v s. Kozari Rogatinskogo poveta [Sixth grader public school with Polish-Ukrainian language of instruction in the village Kozari of Rogatyn district] (Fund 590. Inventory 1. File 1). State Archive of IvanoFrankivsk Region, Ivano-Frankivsk [in Russian].

\section{FEATURES OF SCHOOL UKRAINIZATION IN THE WESTERN REGION OF UKRAINE IN THE FIRST HALF OF THE TWENTIETH CENTURY}

The publication concerns the study of historical and pedagogical developments on the problem of Ukrainiization of schools in the Western region of Ukraine in the early twentieth century.

The article contains analysis of the features and important factors of preservation of the Ukrainian school and education: social and political (collapse of empires and establishment of WUPR, artificial territorial demarcation, violent policy of foreign states and existence within such states, lack of rights for full education for Ukrainians), economic (backwardness, weak development of the economy and industry), cultural (low level of general culture development, contempt for the Ukrainian population etc.).

Based on the analysis of the source base (archival materials, scientific researches of modern scientists), the publication identifies important problems, directions, means of preserving the Ukrainian language and school.

The author expands the idea of the opportunities for schools and teachers to preserve Ukrainian ideas and the nation as a whole in Western Ukraine in the early twentieth century.

The article proves the idea of national education as the main goal of the school, namely the fact 
that Western Ukrainian educators constantly took care of the problems of school development, which resulted in Ukrainian studies in correspondence with the purpose and content of education.

The article finds that the preservation and development of the Ukrainian national school was facilitated by the expansion of the network of private educational institutions, including private gymnasiums.

The studied historical and pedagogical research allowed to single out the conditions for the preservation of the Ukrainian school, to focus on the features of the courses in the schools of Western Ukraine in the early twentieth century, which had a great impact on its Ukrainization.

The author emphasizes the need to study the research dedicated to the problems of Ukrainization of the school at that time for the sake of detailed scientific study, extrapolation of experience in modern schooling.

Key words: Western Ukraine, national school, Ukrainization, nationalization, school education, Ukrainian language.

\section{СТАНОВАЕННЯ ПІСАЯДИПЛОМНОЇ ОСВІТИ ПЕДАГОГІЧНИХ ПРАЦІВНИКІВ ЗАКЛАДІВ ДОШКІЯЬНОЇ ОСВІТИ УКРАЇНИ (50-ТІ РОКИ ХХ СТОЯІТТЯ)}

Статтюо присвячено висвітленню історико-педагогічного аспекту особливостей становлення підвищення квалібікацї педагогічних працівників закладів дошкільної освіти Украйни. Виявлено чинники, які сприяли початку становлення системи підвищення кваліфікацї̈ педагогічних працівників дитячих садків на початку 50-тих років ХХ століття. Схарактеризовано основні подї означеного періоду, впродовж якого відбувалося накопичення досвіду підвищення квалібікації та становлення змісту післядипломної освіти.

Визначено, щцо у досліджуваний період задля забезпечення підвищення квалібікації педагогічних працівників дитячих садків України органи народної освіти спрямовували свою увагу на виконання директив і вказівок Міністерства освіти УРСР.

Установлено, що центром підвищення квахіфікації були кабінети дошкільного виховання при обласних інститутах удосконалення квахіфікації вчителів. Основними формами професійного розвитку педагогічних працівників була курсова та семінарська перепідготовка, а також методичні об'єднання, науково-практичні конференції, вивчення, узагальнення і поширення передового досвіду, консультациї з питань виховної роботи з дітьми.

Під час теоретичних та практичних занять на курсах підвищення квалібікації висвітлювалися питання, необхідні як для організації роботи закладу дошкільної освіти, так і особливості організациї роботи з дітьми дошкільного віку. Серед лекторів були працівники педагогічного та сільськогосподарського інститутів, працівники обласного відділу народної освіти, інституту удосконалення кваліфікації учителів, а також кращі викладачі педагогічних училищ, та вчителі шкіл міста.

Перспективи наступних наукових пошуків полягають у вивченні питання практичного використання матеріалів дослідження в сучасній післядипломній освіті щзоо організації підвищення кваліфікації педагогічних працівників закладів дошкільної освіти.

Ключові слова: післядипломна освіта, перепідготовка, педагогічні працівники закладів дошкільної освіти, інститут удосконалення кваліфікацї вчителів, форми підвищення кваліфікаціï.

*C Швед Г. В.

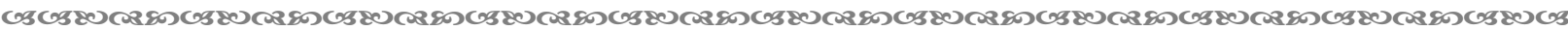
270 